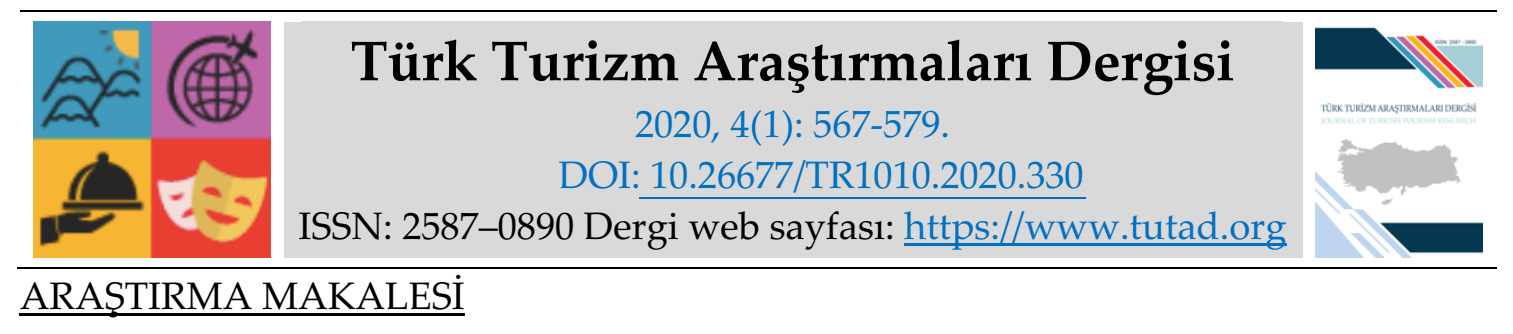

\title{
Turist Rehberlerinin Gözlemlerinden Turistlerin Gastronomik Tercihlerinin Saptanmasi*
}

Dr. Mahmut EFENDİ, Bağımsız Araştırmacı, e-posta: efendimahmut926@gmail.com ORCID: https://orcid.org/0000-0002-7388-5239

Dr. Öğr. Üyesi Hakan ATAY, Aydın Adnan Menderes Üniversitesi, Turizm Fakültesi, Aydın, e-posta: hatay@adu.edu.tr

ORCID: https://orcid.org/0000-0003-4080-8250

\section{$\ddot{O ̈ z}$}

Turist rehberleri hizmet ettikleri ülkenin kültür elçileri olarak görülmektedirler. Yemek kültürü de genel kültür içinde bir alt kültür olarak değerlendirildiğinde turist rehberlerinin hizmet ettikleri yabancı grupla olan gastronomi iletişimleri büyük önem arz etmektedir. Paket turlarda ya da günübirlik turlarda turist rehberlerinin grupları yeme içme etkinlikleri için nasıl yönlendirdikleri bu noktada önemli ve dikkate değer bir araştırma sorusu olarak karşımıza çıkmaktadır. Çalışma bu keşifsel yönüyle gastronomi literatüründe kritik bir boşluğu dolduracaktır; buna ek olarak turist rehberlerinin gastronomi yaklaşımlarının anatomisini ortaya çıaracağı için turist rehberliği pratiğinin gastronomi yapısının anlaşılmasını sağlayacaktır. Bu çalışma nitel araştırma yaklaşımıyla tasarlanmıştır. Araştırma alanı 32 turist rehberinden oluşmaktadır. Veri toplamada yarı yapılandırılmış görüşme tekniğinden faydalanılmıştır. Toplanan veri içerik analizine tabi tutularak belirli temalar altında sınıflandırılmıştır. Sonuç olarak turist rehberinin bir turda grubu yönlendirmesi grubun büyüklüğüne bağlıdır. Büyük gruplarda açık büfe yemek olanakları veya kapasitesi büyük ve hızlı hizmet sunan restoranlar tercih edilmektedir. Bunların yanında turistlerin öncelikli kriteri temizlik ve hijyendir.

*Bu çalışma Nevşehir Hacı Bektaş Veli Üniversitesi Turizm Fakültesi'nde düzenlenen 4. Uluslararası Gastronomi Turizmi Araştırmaları Kongresinde sunulmuştur.

Anahtar Kelimeler: Turist Rehberleri, Gastronomi, Gastronomik Tercihler.

Makale Gönderme Tarihi: 18.11.2019

Makale Kabul Tarihi: 16.01 .2020

\section{Önerilen Atıf:}

Efendi, M. ve Atay, H. (2020). Turist Rehberlerinin Gözlemlerinden Turistlerin Gastronomik Tercihlerinin Saptanması, Türk Turizm Araştırmaları Dergisi, 4(1): 567-579.

(C) 2020 Türk Turizm Araştırmaları Dergisi. 


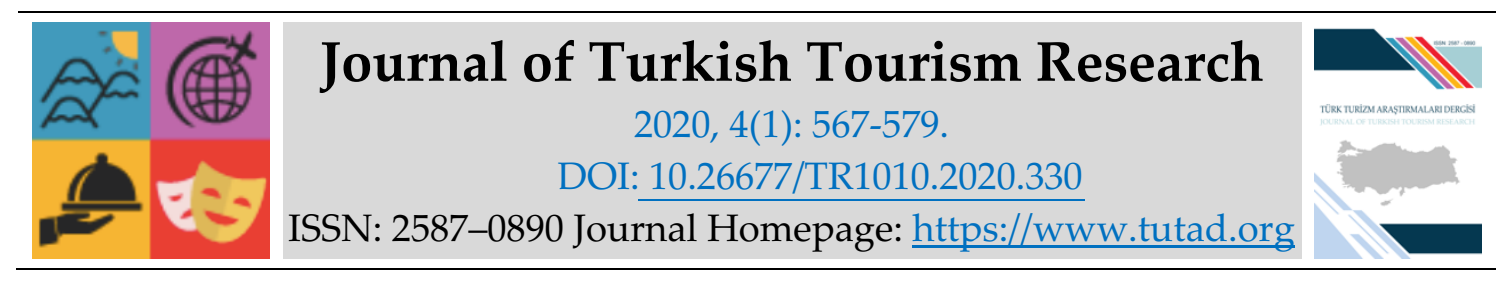

\title{
$\underline{\text { RESEARCH PAPER }}$
}

\section{Determination of Gastronomic Preferences of Tourists from Observations of Tourist Guides}

Dr. Mahmut EFENDİ, Independent Researcher, e-mail: efendimahmut926@gmail.com ORCID: https://orcid.org/0000-0002-7388-5239

Assistant Prof. Dr. Hakan ATAY, Aydın Adnan Menderes University, Faculty of Tourism, Aydın, email: hatay@adu.edu.tr

ORCID: https://orcid.org/0000-0003-4080-8250

\begin{abstract}
Tourist guides serve as a bridge between the culture of the tourist they serve and the culture of their country of origin. At this point, how tourist guides guide groups for eating and drinking activities in package tours emerges as an important and remarkable research question. This exploratory aspect of the study will fill a critical gap in the gastronomic literature. In addition, it will provide an understanding of the gastronomic structure of tourist guidance practice as it will reveal the anatomy of the gastronomic approaches of tourist guides. This study was designed with qualitative research approach. Observations and possible directions of the tourist guides about the gastronomic experiences of the tourists constitute the research question. Semi-structured interview technique was used for data collection. The collected data were subjected to content analysis and grouped under certain themes. As a result, the tour guides guiding group in a tour depends on the size of the group. In large groups, buffet dining facilities or restaurants with large capacity and fast service preferred. In addition, the priority criteria of tourists are cleaning and hygiene.
\end{abstract}

Keywords: Tourist Guides, Gastronomy, Gastronomic Preferences.

Received: 18.11 .2019

Accepted: 16.01 .2020

\section{Suggested Citation:}

Efendi, M. and Atay, H. (2020). Determination of Gastronomic Preferences of Tourists from Observations of Tourist Guides, Journal of Turkish Tourism Research, 4(1): 567-579.

(C) 2020 Türk Turizm Araştırmaları Dergisi. 


\section{GíRiş}

Bilgi ve iletişim teknolojilerinde meydana gelen hızlı ve radikal gelişmelerle birlikte insanların yaşam biçimlerinde farklılıklar meydana gelmeye başlamıştır (Okul ve Şimşek, 2018). Yemek yemek insanların yaşamsal fonksiyonlarını gerçekleştirebilmeleri açısından hayati bir önem taşımaktadır. Günümüz toplumları, büyük boyutlara ulaşmış olan yiyecek içecek hizmetleri endüstrisinin ürettiği ürün ve hizmetleri giderek artan oranlarda tüketmektedirler. Ayrıca hangi yemeğin hangi malzemeleri içereceği, hangi araç gereçle hazırlanıp nasıl pişirileceği toplumdan topluma farklılık gösteren bir durumdur (Albayrak, 2013).

Her milletin, ülkenin yapısı ve alışkanlıklarına göre kendi mutfağı vardır. Orta Asya'nın sade yemeğinden zengin Selçuklu ve Osmanlı Mutfağına yol açılmış, Çin ve Fransız Mutfağı ile birlikte Türk Mutfağ (Şanlıer, 2005). Türk mutfağı, gerek zengin içeriği, gerekse sahip olduğu kültürel özellikleri ile turizm endüstrisi için kritik öneme sahiptir (Cömert, 2014). Misafirperverlik ve gastronomi arasında bir akrabalık ilişkisi bulunmaktadır çünkü yiyecek ve içecekler insanlar arasındaki iletişim araçlarıdır (Santich, 2007).

Turistleri bir ülkeyi, bölgeyi veya yeri ziyaret etmeye motive eden ana faktörler o yerin çekicilik unsurlarından oluşmaktadır. Bir bölgeyi diğer bölgelerden ayıran çekicilik unsurlarına o ülkenin genel kültürü, doğal güzellikleri, toplumsal özellikleri, tarihi değerleri, sanat faaliyetleri, spor faaliyetleri, eğlence ve alışveriş olanakları ve mutfağı örnek gösterilebilir (Selwood, 2003).

Bu çalışmada turist rehberlerinin gözünden turistlerin yeme içme tercihleri incelenmiştir. Paket turlarda ya da günübirlik turlarda turist rehberlerinin grupları yeme içme etkinlikleri için nasıl yönlendirdikleri önemli ve dikkate değer bir araştırma sorusu olarak karşımıza çıkmaktadır. Bu sorunun yanıtlanması ülkemiz turizmi açısından gastronomi tercihlerin hangi motivasyonlarla yapıldığının anlaşılması ve turistlerin yeme içme deneyimlerinin niteliğinin saptanması noktasında büyük bir öneme sahiptir. Çalışma bu keşifsel yönüyle gastronomi literatüründe kritik bir boşluğu dolduracaktır; buna ek olarak turist rehberlerinin gastronomi yaklaşımlarının anatomisini ortaya çıkaracağı için turist rehberliği pratiğinin gastronomi yapısının anlaşılmasını sağlayacaktır.

\section{KAVRAMSAL ÇERÇEVE}

Yemek, bir toplumun kendisini ve yaşama tarzını ifade etmekle birlikte kültürün en önemli unsurlarından biridir. İnsanlar farklı bölgelerin farklı kültürlerini öğrenirken o bölgenin kültürünü yansitan farklı lezzetleri de tatmak ve öğrenmek istemektedir (Özer, 2018: 16). Bir bölgeye özgü yemekler, o bölge için diğer bölgelere göre fark yaratmaktadır. Turistler için sunulan yiyecek ve içecek türleri, turizm destinasyonları için ekonomik, kültürel ve çevresel sürdürülebilirlik içerisinde yer almaktadır (Sims, 2009: 321, Canbolat, Keleş ve Akbaş, 2016: 83, Girgin, 2018: 794). Günümüzde insanlar sadece açlık duygusunu gidermek için değil aynı zamanda o yemek sürecinde farklı deneyimleri yaşamak amacıyla evlerinden dışarıda yemek yemektedirler (Gülen, 2017).

Turist tercihlerinde değişimler yaşandığı ve geleneksel deniz-kum-güneş odaklı ürünler dışında farklı arayışlar olduğu görülmektedir (Zağralı ve Akbaba, 2015). Tüketiciler artık bilgi arayışından öte deneyim arayışı içerisine girmişlerdir. Turistler ürün ve hizmet almanın yanında tüketilen ürün ve hizmetlerle ilgili deneyimleri elde etmek için çaba harcamaktadırlar (Eryılmaz ve Şengül, 2016) ve bu çabaya bağlı olarak turistik deneyimlerinde artışlar olmaktadır (Özdemir, 2010).

Turistler gittikleri bölgede ister zorunlu ihtiyaçlarını karşılamak isterse de haz duymak için olsun yemek-içmek zorundadır. Dolayısıyla haz almak isteyenlere gastronomi rehberleri tarafından özel gastronomi turlarında, diğerleri için de farklı turlarda (kültür, doğa, şehir, müze vb.) gastronomiye ihtiyaç vardır (Akay ve Özöğütçü, 2018). Turistlerin destinasyon seçimini yerel yemekler etkilemektedir (Fields, 2002: 37). Turistler genellikle ziyaret ettikleri yerlerin yerel yemeklerini denerler. Bazı turistler, 
yöresel yemek deneyimleri için tur rehberleri bile isteyebilir. Bu turistler için, yerel yemeklerin tadını çıkarmak, seyahat etmenin en büyük motivasyonudur ve yöresel yemeklerin tadına varan turistler kendi kültürlerinden farklı bir kültür deneyimi yaşayabilir (Yuan, 2015). Semerci ve Akbaba (2018: 52)'e göre; "Kültürel Deneyim" faktörünün, yabancı turistlerin yerel yemek tüketiminde en çok etkili olan faktör olduğu görülmektedir.

Gastronomi; gıda bilimini, yemek sanatını ve lezzet yaratıcılığını birleştirerek beslenme zevkini ortaya çıkaran ve bunlara ek olarak kültür ve yemek arasındaki ilişkiyi inceleyen bir disiplin olarak tanımlanabilir (Gökdeniz vd, 2015). Gastronomi sözcüğü ilk kez Fransız şair ve yazar Joseph Berchoux tarafından kullanılmıştır ve köken olarak Yunanca'daki gastro (mide) ve nomos (kural) sözcüklerinin birleşimiyle meydana gelmiştir. İnsanlara neyin, nerede, ne zaman, hangi şekilde, hangi kombinasyonlarla yenilebileceği ve hangi içeceklerin bu kombinasyona eşlik edeceği ile ilgili bir rehberdir (Santich, 2004). Bu bağlamda gastronomi, "insan refahı ve gidasını ilgilendiren her konuda sağlanmış kapsamlı bilgi birikimi" olup; sağllğa uygun, iyi düzenlenmiş, hoş ve lezzetli mutfak, yemek düzeni ve sistemini ifade etmektedir (Altınel, 2009). Turizm açısından gastronomi, gerek iç gerekse dış turizmin vazgeçilmez bir unsurudur (Aslan, 2010). Turistik çekiciliklerden biri olan yöresel mutfak unsurları, turizm destinasyonunun pazarlanmasında ve diğer turizm destinasyonlarından ayrılmasında önemli bir unsur olarak ortaya çımaktadır (Mak, Lumbers, Eves and Chang, 2012; Aksu, Gezen ve Özcan, 2017).

Bir ülkenin mutfak kültürü o ülkeyi ziyaret eden yabancı turistlerin tatil deneyimleri içerisinde önemli yer tutmaktadır. Bu nedenle farklı milletlerden ülkemize gelen turistlerin Türk mutfağına ilişkin görüşleri hakkında bilgi sahibi olmak turizm endüstrisine önemli katkı sağlayacaktır (Albayrak, 2013). Her şeyden öte turistler katıldıkları turlarda turist rehberleriyle beraber dolaşmaktadırlar ve buna bağlı olarak öncelikle turist rehberinden bahsetmek gerekmektedir.

Çolakoğlu, Efendi ve Epik (2014: 157) tarafından yapılan araştırmada, turist rehberleri üç gruba ayrılmaktadır: Genel kültür rehberi, uzman rehber ve nokta rehber. Genel Kültür rehberi, "faaliyette bulundukları ülke ve bölge ile ilgili her konuda derinlemesine olmamakla birlikte, bilgi sahibi olan, birçok güzergâhta kullanılabilecek rehberlerdir". Uzman rehber, "daha çok özel ilgi turizmi kapsamında düzenlenen turlarda görev alan ve belli konuları çok derinlemesine özümsemiş kişilerdir". Nokta rehber ise "grupla birlikte yolculuk etmeyen, yalnızca belli bir noktada grupla buluşup, onlara o yer hakkında rehberlik hizmeti sunan kişilerdir."

Turist rehberliği mesleği, bir ülkenin kültürel, tarihi ve doğal değerlerinin tanıtımını yapma ve kültür elçisi olarak ulusal ve uluslararası ilişkilerde etkili olma açısından oldukça önemli bir konuma sahiptir (Ap ve Wong, 2001; Başoda, Aylan, Kılıçhan ve Acar, 2018). Ayrıca turist rehberleri yeme ve içme kültürü hakkında turistlere doğru bilgi aktarmakla yükümlüdürler (Köroğlu, 2013). Bunun yanında gastronomi zenginliğinin uzman rehberler tarafından tanıtılması, ülke turizmi için oldukça önemlidir (Köroğlu ve Güdü Demirbulat, 2017). Bu bağlamda çalışmanın önemi bir kez daha dikkat çekmektedir.

\section{YÖNTEM}

Bu çalışma nitel araştırma yaklaşımı ile tasarlanmıştır. Turistlerin gastronomi deneyimleri ile ilgili turist rehberlerinin gözlemleri ve olası yönlendirmelerinin neler olabileceği araştırma sorusunu oluşturmaktadır. Bu yönüyle keşifsel bir özelliğe sahiptir ve gastronomi araştırmaları yazınında daha önceden girilmemiş bir alanı incelemektedir. Araştırma alanı 32 turist rehberinden oluşmaktadır. Çalışma için yapılan görüşmelerde turist rehberleri seçilirken kolayda örneklem yöntemi seçilmiştir. Turist rehberlerinin seçiminde ayrıca yıl içerisinde 2019 eylemli olmaları dikkate alınmıştır. Rehberlerin $11^{\prime} \mathrm{i}$ kadın $21^{\prime} \mathrm{i}$ erkektir ve ortalama yaş düzeyi $35^{\prime}$ tir ve $\% 76$ 'sı 10 ve daha fazla yıllık deneyime sahiptir. Aydın Turist Rehberleri Odası'na (ATRO) bağlı olarak aktif görev yapan katılımcılara ulaşılarak gönüllülük esası ile çalışmaya katılmaları rica edilmiştir. Veri toplamada yarı yapılandırılmış görüşme tekniğinden faydalanılmıştır. Yarı yapılandırılmış görüşme tekniğinin seçilme nedeni, araştırmacıların 
hazırlamış olduğu soruların yanında ek sorular sorabilme imkânı bulması ve araştırmanın daha derine inmesine olanak sağlamasıdır. Görüşmeler yaklaşık olarak $45 \mathrm{dk}$. süre almış ve veriler içerik analizi yöntemiyle düzenlenmiştir.

Yarı yapılandırılmış görüşmelerde rehberlere yöneltilen sorular şunlardır:

1. Turlarda serbest zamanda grubunuzu götüreceğiniz yere karar verirken nelere dikkat ediyorsunuz? (Ek soru: Grubunuz gidilecek yer konusunda sizi yönlendiriyor mu? Bu yönlendirmede turistler neleri gözetiyor?)

2. Yemeğe götürdüğüz grupları gidilen yerde neler memnun ediyor, neler tatminsizlik yaratıyor?

3. Turistler yiyecek/yemek tercihlerini nasıl yapıyor?

4. Turistin bir yemeği beğenmesi veya beğenmemesinin nedenleri nelerdir?

5. Yemek yenilen yerlerde yaşanılan sorunlar nelerdir? (Ek soru: Ufak çaplı krizlere yol açan sorunlar oluyor mu? Büyük çaplı krizlere yol açan sorunlar oluyor mu?)

Yukarıdaki sorulara verilen yanıtlardan elde edilen veriler içerik analizine tabi tutularak belirli temalar altında gruplanmıştır.

\section{BULGULAR}

Araştırmadan elde edilen bulgulara bakıldığında sorulan ilk soruya göre (Turlarda serbest zamanda grubunuzu götüreceğiniz yere karar verirken nelere dikkat ediyorsunuz?) turist rehberleri gruplarını bir yeme içme tesisine götürmeye karar verirken tesisle ilgili önem sırasına göre en çok hijyene, temizliğe, fiyatların ekonomik olmasına, servisin hızlı ve kaliteli olmasına, yemek lezzetinin memnun edici olmasına, gidilen yerin yöresel ve otantik olmasına, çalışan davranışlarının kalitesine, makul düzeyde bir komisyon verilmesine, lavabo ve market kalitesine, tesisin büyük grupları kaldırma kapasitesine dikkat etmektedirler. Turist rehberleri bu soruya birden fazla cevap vermişlerdir ve bu cevaplar aynı önem derecesine göre sıralanmıştır. Tablo 1' de ilk soruya verilen yanıtların daha ayrıntılı bir dökümü yer almaktadır:

Tablo 1. Yemek Yenecek Yerin Seçiminde Turist Rehberlerinin Gözettiği Unsurlar

\begin{tabular}{|l|l|}
\hline Gözetilen Unsur & Frekans \\
\hline Mekanın hijyenik olması & 8 \\
\hline Mekânın temiz olması & 7 \\
\hline Fiyatların ekonomik olması & 7 \\
\hline Servisin hızlı ve kaliteli olması & 6 \\
\hline Çalışanların tutum ve davranışlarının profesyonel olması & 4 \\
\hline Memnun edici lezzet & 3 \\
\hline Makul düzeyde bir komisyon verilmesi & 3 \\
\hline Lavabo ve market kalitesi & 3 \\
\hline Tesisin büyük grupları kaldırma kapasitesi & 3 \\
\hline
\end{tabular}


Tablo 1'de verilen cevaplarda frekans ayrımı yapılırken sorulan soruya verilen birkaç cevapların tümü dikkate alınmıştır. Bu bağlamda ilaveten yapılan görüşmelerde turist rehberlerinin verdikleri ek bilgilere göre, turist rehberleri eğer büyük gruplara hizmet ediyorlarsa daha çok açık büfe hizmet veren ve büyük gruplara sorunsuz hizmet edebilecek tesislere yönelmektedirler. Eğer grup küçükse daha çok otantik ve yöresel/butik tesisler tercih edilmektedir. Ayrıca gidilen yerin revaçta olması, kaliteli vakit sunma olanakları sağlaması, araç otopark ve yararlanılan araç için manevra alanları, turistin milliyeti, yemek çeşitliliği, işletme sahibinin mekânda grubu karşılaması ve sürekli mekânda bulunabilmesi, gidilen yerin konumu da turist rehberlerinin yemek yeme yeri seçimine etki eden diğer faktörler olarak saptanmıştır.

Birinci soruya ek olarak sorulan "Grubunuz gidilecek yer konusunda sizi yönlendiriyor mu? Bu yönlendirmede turistler neleri gözetiyor?" sorusuna verilen yanıtlara bakıldığında turist rehberlerinin büyük çoğunluğunun (21 turist rehberi) bu noktada iki kriteri olduğu saptanmıştır. Buna göre turist rehberleri eğer grup küçükse ve yemek ücreti turist tarafından ödenecekse (tur fiyatına dahil edilmemişse) turistlerin yemek yenecek yerin seçiminde karar vermesine olanak sağlamaktadırlar. Turist rehberlerinden elde edilen bulgulara göre turistlerin yemek yenecek yer seçiminde dikkate aldıkları kriterler Tablo 2'de görülmektedir:

Tablo 2. Turistlerin Yemek Yenilecek Yer Seçiminde Dikkate Aldıkları Unsurlar

\begin{tabular}{|l|c|}
\hline Gözetilen Unsur & Frekans \\
\hline Yöresellik ve otantiklik & 3 \\
\hline Vejetaryen ve vegan beslenme olanağı, glüten alerjisi & 2 \\
\hline Turistin bütçesi & 1 \\
\hline Mekânın sosyal medyada popüler olması & 1 \\
\hline Turistin damak tadına uygunluk & 1 \\
\hline Önceden araştırılmış olan tanınmış şeflerin varlığı & 1 \\
\hline Lezzet ve hijyen & 1 \\
\hline Türk mutfağı ve etli ev yemeklerinin servis edilmesi & 1 \\
\hline
\end{tabular}

Müşterinin rehberi yönlendirmesi grubun büyüklüğü ile çok yakından ilişkilidir. Grubun göreli olarak küçük olduğu ve ücretin turist tarafından ödendiği (tur fiyatına dahil olmadığı) durumlarda rehberler turistin yönlendirmesine daha fazla imkan tanımaktadırlar. Böyle durumlarda turistlerin en çok dikkat ettiği unsur tesisin yöreselliği ve otantikliğidir. Bundan başka vejetaryenlik, veganlık ve glüten alerjileri seçimde etkin olmaktadır. Ayrıca turistlerin bütçesi, mekanın sosyal medya popülerliği, mekandaki şefin ünlü olması, turistin damak tadı (kendi yemek kültürüne yakın tatlar arama), lezzet ve hijyen, mekanda Türk ev yemeklerinin olması (kebap ve balık ağırlıklı) tercih edilmektedir.

Yemek için gidilen tesiste turistleri memnun eden ve etmeyen unsurlarla ilgili bulgular Tablo 3'te yer almaktadır: 
Tablo 3. Yemek İçin Gidilen Tesiste Turistleri Memnun Eden/Etmeyen Unsurlar

\begin{tabular}{|c|c|}
\hline Memnun Eden Unsurlar & Memnun Etmeyen Unsurlar \\
\hline $\begin{array}{l}\text { Turist rehberinin yemek sırasında ya da } \\
\text { sonuna doğru masaları dolaşıp herhangi bir } \\
\text { ihtiyaç olup olmadığını sorması ile müşteri } \\
\text { memnuniyeti artmakta }\end{array}$ & $\begin{array}{l}\text { Yemek için gidilen restoranda, restoran yöneticisinin } \\
\text { ve turist rehberinin turistlere karşı ilgisiz tavırları, }\end{array}$ \\
\hline $\begin{array}{l}\text { Yemek düzeninin standartlara uyması } \\
\text { (uluslararası kriterler) }\end{array}$ & $\begin{array}{l}\text { Turistin beklentilerinin çok yüksek olması (örneğin } \\
\text { ülkesinde yediği yemeğin aynısını bulma isteği) }\end{array}$ \\
\hline Fiyatların uygun olması & Fiyat/kalite orantısızlığı \\
\hline $\begin{array}{l}\text { Yaz aylarında klimalı ve kışın sıcak bir } \\
\text { restoran }\end{array}$ & Yaz aylarında sıcak ve kışın soğuk restoran, \\
\hline Personelin turistin konuştuğu dili bilmesi & İlgisiz personel (dil bilmeyen ve lakayit personel) \\
\hline Doğal ve taze malzemeler kullanılması & $\begin{array}{l}\text { Çeşit bol görünsün diyerek abur cubur ile doldurulan } \\
\text { ve bayat malzeme kullanılan açık büfeler (mide } \\
\text { rahatsızlığına yol açmakta) }\end{array}$ \\
\hline Eski/otantik Türk yemeklerinin sunulması & $\begin{array}{l}\text { Açık büfenin dağınık olması ve çok sıra beklenmesi, } \\
\text { ayrıca yemeklerin bayat görünmesi, soğuk servis } \\
\text { edilmesi ve düşük kalite malzeme kullanımı }\end{array}$ \\
\hline Çay ve tatlı ikramı & İkramların olmaması \\
\hline $\begin{array}{l}\text { Lüks restoranlardan daha ziyade aile } \\
\text { restoranı olması }\end{array}$ & Aşırı kalabalık restoranlar \\
\hline Güzel dekorasyon & Mekânın iç ve dış görünümünün kötü olması \\
\hline
\end{tabular}

Tablo 3'te de görüldüğü gibi turistleri otantik, küçük ve güler yüzlü/ilgili personelin olduğu mekânlar memnun etmektedir. Açık büfenin özensiz olduğu, ilgisiz personeli olan ve yüksek fiyata düşük kalitede servis veren tesisler de tatminsizlik yaratmaktadır.

Turistlerin yemek tercihlerinin milliyetlerine göre değişip değişmediğine yönelik sorulan soruya verilen yanıtlardan elde edilen bulgular şöyledir. Asyalı turistlerin kendi mutfaklarını, ayrıca balık ve et ürünlerini tercih ettikleri anlaşılmaktadır. İngilizlerin kızarmış balık ve patates tercih ettikleri, Amerikalıların alakart restoran ve kaliteli şarap tüketmeyi tercih ettikleri, Hintlilerin bol baharatlı ve vejetaryen yemekleri tercih ettikleri, Latin Amerikalıların kırmızı et tercih ettikleri, Malezya ve Endonezyalı turistlerin acılı baharatlar ihtiva eden yemekler tercih ettikleri saptanmıştır.

Bir turistin yemeği beğenip beğenmeme sebepleri ayrıca bir soru olarak sorulmuştur. Bu sorunun sorulma amacı turistin tesise yönelik genel tutum ve görüşlerinden yemeklere yönelik daha mikro ölçekte veriler elde etmektir. Bu soruda herhangi bir yemek çeşidi dikkate alınmamış olup rehberlerin bu yöndeki genel izlenimleri dikkate alınmıştır. 
Tablo 4. Turistlerin Yemeği Beğenip Beğenmeme Sebepleri

\begin{tabular}{|l|l|}
\hline Yemeği Beğenme Sebepleri & Yemeği Beğenmeme Sebepleri \\
\hline Yemeğin iyi bir sunuma sahip olması & Yemeğin iyi bir sunuma sahip olmaması \\
\hline Yemeğin hijyenik olması & $\begin{array}{l}\text { Yemeğin hijyen kurallarına uygun pişirilmemesi } \\
\text { (bonesiz ve kirli önlük) }\end{array}$ \\
\hline Restoranın atmosferi & Restoranın kirli ve düzensiz olması \\
\hline & Yemeğin daha önceden denenmiş olması \\
\hline & Yemeğin damak tadına uymaması \\
\hline & $\begin{array}{l}\text { Fazla hamurlu yiyecekler (börek, gözleme vb.) } \\
\text { sevilmeyip yarım bırakılıyor }\end{array}$ \\
\hline & Tatlıların çok şerbetli ve şekerli olması \\
\hline
\end{tabular}

Tablo 4'te de görüldüğü gibi hijyenik, göze hitap eden ve iyi bir sunumu olan yemekler beğeni kazanırken; fazla pişen, zamanında servis edilmeyen, fazla yağlı, hamurlu ve tuzlu yemekler beğeni kazanmamaktadır.

Yemek yenilen yerde yaşanan büyük çaplı kriz yaratan sorunlar veya ufak çaplı kriz olaylarının olup olmadığına yönelik sorulan soruya verilen yanıtlardan elde edilen bulgular şunlardır:

Tablo 5. Yemek Yenilen Yerde Sorun Yaratan Unsurlar

\begin{tabular}{|l|c|}
\hline Yaşanılan Sorun & Frekans \\
\hline Yetersiz ve hijyenik olmayan tuvaletler & 4 \\
\hline Servis için uzun süre sıra beklenmesi & 4 \\
\hline Yabancı dil konuşan eleman bulunmaması (özellikle kasada) & 3 \\
\hline Porsiyonların küçük olması & 2 \\
\hline Masa konumunun kötü olması veya müşterinin istediği yere oturamaması & 2 \\
\hline Restoranın kalabalık olması (restoranın değişmesine neden olabiliyor) & 2 \\
\hline Vejetaryen yemeğinden et çıkması & 1 \\
\hline Servis personelinin sert ve kaba tutumları & 1 \\
\hline Temiz tabakların içine kirli tabak-çatal karışması & 1 \\
\hline Restoranda sadece alaturka tuvalet bulunması & 1 \\
\hline Yemekten kıl çkması & 1 \\
\hline Otelde verilen yemeğin kaçırılması & 1 \\
\hline $\begin{array}{l}\text { Yemeklerin alerjen içeriklerinin (et, süt, yumurta, un, susam, fındık, fıstık vs.) } \\
\text { yeterince açık belirtilmemesi }\end{array}$ & 1 \\
\hline Masaların temizlenmemiş olması & 1 \\
\hline Grup tarafından paylaşıması istenen ortaya sunum yemekler & 1 \\
\hline Cevap vermeyen turist rehberleri & 6 \\
\hline
\end{tabular}

Tablo 5'te de görüldügüü gibi yemek yenilen yerde sorun yaratan (küçük çaplı kriz yaratan) unsurların başında yetersiz ve hijyenik olmayan tuvaletler, uzun süre servis sırası beklenmesi, servis personelinin kaba davranışları, yabancı dil bilen eleman eksikliği, porsiyonların küçük olması, masa konumunun kötü olması, masaların temizlenmemiş olması, restoranın kalabalık olması gibi unsurlar tekrarlanma sıklığı açısından dikkat çekmektedir. Bunun yanında büyük çapta kriz yaratan sorunlar, vejetaryen yemeğinden et çıkması, sunulan yemekten kıl çıkması, otelde verilen yemeğin kaçırılması (saatin hatalı hesaplanıp otele geç girilmesi), grup tarafından paylaşılması istenen ortaya sunum yemekler ve yemeklerin alerjen içeriklerinin bulunmasıdır. 


\section{SONUÇ VE ÖNERILER}

Turizm, farklı kültürlerin ve yöresel lezzetlerin tanıtılması için önemli bir araçtır (Serçeoğlu, 2014: 44). Destinasyonların kültürünü yansıtan yerel yemeklerin turist tercihlerini etkileyen bir etken olarak her geçen gün daha fazla önem kazandığı gözlemlenmektedir. Bu bağlamda, bir turist çekicilik etkeni olarak yerel yemeklerin önemi ve rolünün iyi tanımlanması gerekmektedir (Fox, 2007, Zağralı ve Akbaba, 2015: 6641). Farklı bir ülkeye seyahat eden turistlerin birçoğu seyahatler sırasında sadece açlık hissini gidermeye yönelirken, diğer turistler ise seyahat amaçları içerisinde gastronomi bulunmaktadır. Bu bağlamda, dünyada gastronomi deneyimi yaşamak ve belli yörelerdeki ünlü şeflerin yemeklerinden yemek için seyahat eden insanların sayısı her geçen gün artmaktadır (Hall ve Mitchell, 2000: 445, Özer, 2018: 23). Türk mutfağının çeşit zenginliği ve kültürel değişiklikleri yansıtması bakımından köklü dünya mutfakları arasında yer aldığı düşünüldüğünde, ülkemizin de gastronomi turizminde önemli bir pay elde edebileceği söylenebilir (Yetiş, 2015: 17).

Müşteri ile birebir ilişki halinde olan turist rehberlerinin gastronomi turizmi olgusunun Türkiye'de geliştirilmesi bakımından iki farklı rolünden bahsedilebilir. Birincisi, gelişim evresinde bu turizm çeşidinin potansiyel olarak var olduğunu turiste hissettirmek; ikincisi ise, bu alanda kendisini geliştirerek gastronomi turizmi kapsamında hizmet verirken mutfak zenginliğini ve çeşitliliğini doğru biçimde karşı tarafa aktarmaktır (İrigüler ve Güler, 2017: 15). Turist rehberinin bir turda grubu yönlendirmesi grubun büyüklügüne bağlıdır. Büyük gruplarda daha çok açık büfe yemek olanakları veya kapasitesi büyük ve hızlı hizmet sunan restoranlar tercih edilmektedir. Küçük gruplarda rehber seçimi gruba bırakabilmektedir. Böyle durumlarda turistlerin öncelikli kriter temizlik ve hijyendir. Ayrıca restoranın otantik olması ve yöreselliği önem arz etmektedir.

Bunların yanında yöresel yiyecek ve içeceğin turizmde kültürel öğe olarak değer kazanması, yerel halkın bilinçlenerek gelenek göreneğine sahip çıkmasına, kültürel mirasın korunup yaşatılması ve gelecek kuşaklara aktarılmasına katkı sunar. Yöresel yemekler, insanların destinasyon tercihinde önemli rol oynamaktadır. Turistlerin güzel bir tatil deneyimi kazanmalarına yardımcı olur ve daimi bir harcama yapmalarına olanak sağlayarak bölge ekonomisine de katkıda bulunur (Çapar ve Yenipınar, 2016: 110).

Yerel mutfak kültürüne yönelik deneyim; bilinmeyen lezzetleri tatma, keşif; lezzetlere yönelik tüm süreçleri yaşama, katılma; etkinliklerde yer alma ve ziyaret ise özel alanlara/yerlere ziyaret odaklı faaliyetleri kapsamaktadır (Başoda vd., 2018, 1822). Diğer yandan bazı turistler de kendi kültürlerine yakın yemeklerin olduğu restoranları tercih etme eğilimindedirler. Turistlerin bazı yemek çeşitleri ve tatlılar hakkındaki olumsuz düşünceleri Türk yemeklerine alışık olmamaları, yemek ve tatlıların aslına, reçetesine uygun olarak yapılmamasından kaynaklanabilir (Şanlıer, 2005: 222). Bununla beraber yemek tercihleri turistin milliyetine göre değişmektedir. Birdir ve Akgöl (2015: 66) gastronomi turizminin geliştirilmesi açısından yiyecek içecek işletmelerinin; yiyecek içecek işletmelerinde sunulan Türk mutfağına özgü yiyecekler yağ şeker miktarı yönünden dengelenip; kalite, çeşit, görünüş, temizlik, besin değeri açısından geliştirilmeli ve lezzet ve porsiyon açısından beğenilen Türk yemeklerine bu özellikler konusunda standart kazandırılması; Türk mutfak kültürüne özgü eşsiz mutfak değerlerine ve Türkiye' deki destinasyonlarda, bölgelere has yiyecekler ve hazırlama-pişirme yöntemlerine sahip çıkıp ve bu değerlerin korunması gerektiğini belirtmişlerdir.

Turist rehberlerine göre Avrupa, Amerika, Japon ve özellikle Güney Afrikalı müşteriler yeni tatlara açıklar. Bu bağlamda, gastronomi turizmi amacıyla ziyaret edilme isteği konusunda potansiyeli yüksek olan bu bölgelerin ve şehirlerin mutfak kültürü konusunda ön plana çıartılması Türk turizmi için oldukça önem arz etmektedir (Şengül, 2017: 393). Diğer yandan Hint ve Uzakdoğulu turistler kendi damak tadından vazgeçmemekte ve çoğu kez yiyeceklerini yanlarında getirmektedirler. Bunun yanında Hintli turistlerin Türk yiyeceklerini ve mutfağını en çok beğenen millet oldukları, aynı şekilde Türkiye'deki gastronomi tecrübesinden en çok tatmin olan turist grubu olduğu belirlenmiştir (Birdir ve Akgöl, 2015: 66). Milliyetle birlikte dini inançlar da yemek tercihlerini etkilemektedir. Veri toplama sürecinde bu yönde bir soru sorulmasa da bazı katılımcılar özellikle Hintli turistlerin vejetaryen 
mutfağa yönelmesinde din faktörünün önemine dikkat çekmişlerdir. Ayrıca Hıristiyan turistlerin sebze ağırlıklı yemeklere yöneldikleri belirtilmiştir. Özellikle Hintli Jainlerin toprak altından gelen hiçbir şeyi yememeleri tesis seçiminde ciddi sorunlar yaratabilmektedir. Grup Avrupalı ise yemeklerin baharatlı olmasından Asyalı ise baharatlı olmamasından şikâyet edebilmektedir.

Yemek yenilen tesisteki servis elemanlarının tutumları, güler yüzlü ve ilgili olmaları yabancı dil bilmeleri çok büyük önem arz etmektedir. Yabancı dil bilmeyen personel çalıştırılması ufak çaplı krizlere neden olabilmektedir. Turistlerin yerel gida tüketmelerinde etkili olan motivasyonlardan biri de "Kişilerarası İlişki" olduğu göz önünde bulundurulduğunda, yiyecek-içecek hizmeti veren işletmelerde turistler için rahat bir iletişim ortamının oluşturulmasına önem verilmelidir (Girgin, 2018: 806). Tesiste çıkan sorunlar bazen turistin milliyetine bağlı olarak da şekillenebilmektedir. Örneğin bir Alman turist için tuvaletlerin mutfağa yakın olması kabul edilemez bir hijyen ihlalidir. Benzer bir şekilde turist rehberlerinin bir motto gibi tekrarladıkları Hintli ve Malezyalı ayn yerde yemek yiyemez görüşü buna bir örnektir.

Bu çalışmadan elde edilen bulgular hem hali hazırda mesleğini icra etmekte olan turist rehberlerine hem de geleceğin turist rehberi olacak olan aday öğrencilere pratik açıdan son derece değerli bilgiler sunmaktadır. Elde edilen bulguların yaşanmış deneyimlerden oluşması hem turistik restoran sahiplerine hem de turist rehberlerine meslek kalitelerini daha da arttırmaya yarayacak bilgiler sunmaktadır. Bu çerçevede turist rehberlerine, restoran sahiplerine, turizm planlayıcılarına ve araştırmacılara aşağıdaki öneriler sunulabilir:

\section{Restoran Sahiplerine Öneriler:}

- Restoran ve turistik tesis sahibi olan yöneticiler tesislerinin taşıma kapasitesini göz önüne alarak hizmet sunmaya dikkat etmelidirler. Servis süresinin uzun sürdüğü ve oturma düzeninin uygunsuz olduğu restoranlar tepki çekmekte ve müşteriyi kaçırmaktadır.

- Yabancı dil bilmeyen personel çalıştırmamaya dikkat edilmelidir. Turiste kaba ve ters davranmaması için iyi bir akademik eğitim almış veya hizmet içi eğitime tabi tutulmuş personel çalıştırılmalıdır.

- Menüde fiyat ve kalite dengesine dikkat edilmelidir. Servisin ve yemek sunumunun göze hitap etmesine, yemek malzemelerinin temiz ve taze olmasına, hijyene gereken önem verilmelidir.

- Yöresel ve otantik yemeklerin sunumuna önem verilmelidir.

\section{Turist Rehberlerine Öneriler:}

- Turist rehberleri hizmet ettikleri grubun milliyetine, kültürüne ve damak tadına bağlı olarak en uygun restoranı veya tesisi seçmeye özen göstermelidirler.

- Özellikle vejetaryen ve vegan beslenen müşterilerin hassasiyetlerini göz önüne alarak önceden tesisle iletişime geçip herhangi bir sorun yaşanması ihtimalini ortadan kaldırmalıdırlar.

- Turistlerin daha önceden deneyimlemediği yöresel ve otantik mutfaklara ziyaret etmeyi gözeterek Türk mutfağının daha iyi tanınmasına yardımcı olmalıdırlar.

- Gidilen yerin hijyenik ve temiz olmasına özen göstermelidirler.

\section{Turizm Planlayıcılarına Öneriler}

- Ülke tanıtımına katkıda bulunacak olan yerel yemeklerin aldığı ve yemek özelliklerini belirten broşürlerin hazırlanması ve ülke tanıtımında gidilen ülkelerde dağıtılması gastronomi merakları olan turistlerin ülke tercihlerinde etkili olacaktır.

- Turistlerin yoğun veya düşük sezonda tercih ettikleri restoranların kontrollerinin daha dikkatli ve sıklıkla yapılması, ayrıca restoranlarda turistlerin rahatsız oldukları hijyen koşullarının düzeltilmesi ile birlikte turistlerin tercihlerinde ve ülke tanıtımında etkili olacağı düşünülmektedir. 
- Ülke içerisinde düzenlenen festivallerin tanıtımında yabancı turistlerin bulunduğu alanlarda yapılması hatta özel gastronomi festivallerinin hazırlanması ile birlikte turistlerin tercihlerinin artacağı ve ülke ekonomisine katkının artacağı unutulmamalıdır.

\section{Araştırmacılara Öneriler}

- $\quad \mathrm{Bu}$ araştırmada turist rehberlerinin gözünden turistlerin gastronomi tercihleri dikkate alınmıştır. Bu bağlamda gelecekte yapılacak araştırmalar için turistlerle görüşmeler yapılması ve turistlerin birebir tercihlerinin kendilerinden bilgi toplanarak hazırlanan bir çalışmanın da verimli bilgilere sahip olacağı düşünülmektedir.

- Bu çalışma nitel veri toplama yöntemi kullanılarak hazırlanmıştır. Bu bağlamda gelecekte yapılacak araştırmalarda nitel yöntemlerden odak grup görüşmesi turistlerin daha fazla cevap vererek daha farklı bulguların toplanmasına etkili olacaktır.

\section{KAYNAKÇA}

Akay, B. ve Özöğütçü, B. (2018). Turist Rehberlerinin Turlarda Gastronomiyi Kullanmaları Üzerine Bir Araştırma. Journal of Tourism and Gastronomy Studies. 6 (3), 143-153.

Aksu, M., Gezen, A. ve Özcan, S. (2017). Turistlerin Yöresel Mutfak Tercihleri İle İlgili Bir Araştırma: Bozcaada Örneği. Journal of Tourism and Gastronomy Studies, 5 (2), 125-137.

Albayrak, A. (2013). Farklı milletlerden turistlerin Türk Mutfağına İlişkin Görüşlerinin Saptanması Üzerine Bir Çalışma. Journal of Yasar University. 30 (8), 5049-5063.

Altınel, H. (2009). Gastronomide Menü Yönetimi. Yayımlanmamış Yüksek Lisans Tezi, İstanbul Üniversitesi Sosyal Bilimler Enstitüsü, İstanbul.

Ap, J. and Wong, K. K. F. (2001). Case Study on Tour Guiding: Professionalism, Issues and Problems. Tourism Management, 22 (5), 551-563.

Aslan, H. (2010). Gastronomi Turizminin Turizm Programlarnndaki Yeri ve Önemi - Bir Uygulama, Yayınlanmamış Yüksek Lisans Tezi, Selçuk Üniversitesi Sosyal Bilimler Enstitüsü, Konya.

Başoda, A., Aylan, S., Kılıçhan, R. ve Acar, Y. (2018). Gastronomi Uzmanlığı, Turları ve Rehberliği: Kavramsal Bir Çerçeve. Hitit Üniversitesi Sosyal Bilimler Enstitüsü Dergisi, 11 (3), 1809-1826.

Birdir, K. ve Akgöl, Y. (2015). Gastronomi Turizmi ve Türkiye'yi Ziyaret Eden Yabancı Turistlerin Gastronomi Deneyimlerinin Değerlendirilmesi. İşletme ve İktisat Çalışmaları Dergisi, 3 (2), 57-68. Retrieved from https://dergipark.org.tr/tr/pub/iicder/issue/31648/347033.

Canbolat, E., Keleş, Y. ve Akbaş, Y. Z. (2016). Gastronomi Turizmi Kapsamında Samsun Mutfağına Özgü Turistik Bir Ürün: Bafra Pidesi. Journal of Tourism and Gastronomy Studies 4/4, 75-87.

Cömert, M. (2014). Turizm Pazarlamasında Yöresel Mutfakların Önemi ve Hatay Mutfağı Örneği. Journal of Tourism and Gastronomy Studies, 2 (1), 64-70.

Çapar, G. ve Yenipınar, U. (2016). Somut Olmayan Kültürel Miras Kaynağı Olarak Yöresel Yiyeceklerin Turizm Endüstrisinde Kullanılması. Journal of Tourism and Gastronomy Studies 4/Special issue1, 100-115.

Çolakoğlu, O. E., Efendi, E. ve Epik, F. (2014). Tur Yönetimi ve Turist Rehberliği. Ankara: Detay yayıncilık.

Eryılmaz B. ve Şengül, S. (2016). Sosyal Medyada Paylaşılan Yöresel Yemek Fotoğraflarının Turistlerin Seyahat Tercihleri Üzerindeki Etkisi. Uluslararası Türk Dünyası Turizm Araştırmaları Dergisi. 1 (1), 32-42.

Fields, K. (2002). Demand for The Gastronomy Tourism Product: Motivational Factors. A.-M. Hjalager, \& G. Richards in, Tourism and Gastronomy (pp. 36-50). Oxon: Routledge. 
Girgin, G. (2018). Yerel Gıdaların Tüketilmesine Yönelik Turist Motivasyonlarının Ölçülmesi: Antalya'da Bir Uygulama. Atatürk Üniversitesi Sosyal Bilimler Enstitüsü Dergisi, 793-810. Retrieved from https://dergipark.org.tr/tr/pub/ataunisosbil/issue/36559/384399.

Gökdeniz, A., Erdem, B., Dinç, Y. ve Çelik Uğuz, S. (2015). Gastronomi Turizmi: Ayvalık'ta Yerli Turistler Üzerinde Görgül Bir Araştırma. Journal of Tourism and Gastronomy Studies, 3 (1), 14-29.

Gülen, M. (2017). Gastronomi Turizm Potansiyeli ve Geliştirilmesi Kapsamında Afyonkarahisar İlinin Değerlendirilmesi. Güncel Turizm Araştırmaları Dergisi, 1 (1), 31-42.

Hall, M., and Mitchell, R. (2000). Wine Tourism in The Mediterranean: A Tool for Restructuring and Development. Thunderbird International Business Review, 42 (4) 445- 465.

İrigüler, F. and Güler, M. E. (2017). Tourist Guides' Perceptions on Gastronomic Tourism in Turkey, Journal of Tourism and Gastronomy Studies, 5(1), 3-19.

Köroğlu, Ö. (2013). Turist Rehberlerinin İş Yaşamındaki Rolleri Üzerine Kavramsal Bir Değerlendirme. Pamukkale Üniversitesi Sosyal Bilimler Enstitüsü Dergisi, Sayı 16, 91-112.

Köroğlu, Ö. ve Güdü Demirbulat, Ö. (2017). Rehberlikte Sertifikasyon Kalifikasyon ve Uzmanlaşma, Ö. Güzel, V. Altıntaş, İ. Şahin (Eds.) Turist Rehberliği Araştırmaları: Öngörüler ve Uygulamalar. Ankara: Detay Yayıncilı.

Mak, A. H. N., Lumbers, M., Eves, A. and Chang, R. C. Y. (2012). Factors Influencing Tourist Food Consumption. International Journal of Hospitality Management, 31 (1), 928-936.

Okul, T. ve Şimşek, G. (2018). Turizm Öğrencilerinde Siber Zorbalık Mağduriyeti: Adnan Menderes Üniversitesi Turizm Fakültesi Örneği. 4. Uluslar arası Türk Dünyası Turizm Sempozyumu. 19-21 Temmuz 2018. Kastamonu. Türkiye.

Özdemir, B. (2010). Dışarıda Yemek Yeme Olgusu: Kuramsal Bir Model Önerisi. Anatolia: Turizm Araştırmaları Dergisi, 21 (2), 218-232.

Özer Altundağ, Ö. (2018). Turistlere Sunulan yöresel Yemeklerin Makro ve mikrobesin İçeriğinin Sağlık Boyutu: Safranbolu İlçesi Örneği. Safran Kültür ve Turizm Araştırmaları Dergisi, 1 (1) , 16-28.

Santich, B. (2004). The study of gastronomy and its relevance to hospitality education and training. International Journal of Hospitality Management, 23 (1), 15-24.

Santich, B. (2007). The study of gastronomy: A Catalyst Cultural Understanding. The International Journal of the Humanities, 5 (6), 58-59.

Selwood, J. (2003). The Lure of Food: Food as an Attraction in Destination Marketing in Manitoba, Canada, Michael Hall (Ed), Food Tourism Around the World: Management of Development and Markets, Great Britain: Elseiver.

Semerci, H, Akbaba, A. (2018). Bodrum'a Gelen Uluslararası Ziyaretçilerin Yerel Yemek Tüketimindeki Motivasyon Faktörlerinin Değerlendirilmesi. International Journal of Contemporary Tourism Research, 2 (1), 41-57.

Serçeoğlu, N. (2014). Yöre Halkının Mutfak Kültürünü Tanıma Durumunun Tespit Edilmesi: Erzurum İli Örneği. Journal of Tourism and Gastronomy Studies 2/4, 36-46

Sims, R (2009). Food, Place and Authenticity: Local Food and The Sustainable Tourism Experience. Journal of Sustainable Tourism, 17, 321-336.

Şanlıer, N. (2005). Yerli ve Yabancı Turistlerin Türk Mutfağı Hakkındaki Görüşleri. Gazi Eğitim Fakültesi Dergisi, 25 (1), 213-227. 
Şengül, S. (2017). Türkiye'nin Yabancı Turistlerin Türk Mutfağı Hakkındaki Görüşleri. Balıkesir Üniversitesi Sosyal Bilimler Enstitüsü Dergisi, 20 (37), 375-396. Retrieved from https://dergipark.org.tr/en/pub/baunsobed/issue/50163/645178.

Yetiş, A. Ş. (2015). Kapadokya Yemek Kültürü ve Mustafapaşa Beldesi (Sinasos) Örneği. Journal of Tourism and Gastronomy Studies 3/2, 12-19.

Yuan, S. (2015). Reflections on Local Specialties and Gastronomic Tourism. Chinese Studies, 4, 15-19.

Zağralı, E. ve Akbaba, A. (2015). Turistlerin Destinasyon Seçiminde Yöresel Yemeklerin Rolü: İzmir Yarımadasını Ziyaret Eden turistlerin Görüşleri Üzerine Bir Araştırma. Journal of Yasar University. 10 (40), 6633-6644. 